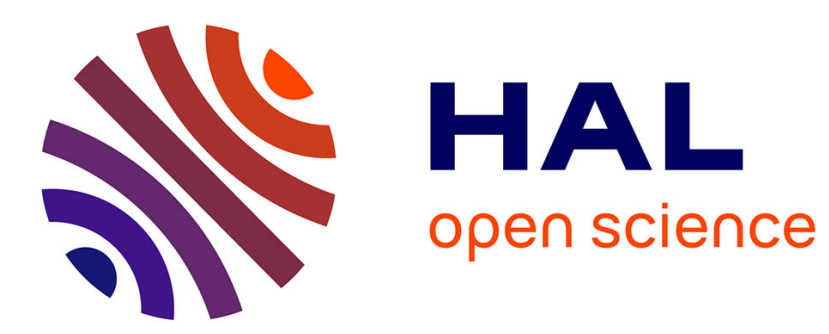

\title{
Ultraviolet-blue plumage colouration can be perceived as an indicator of fluctuating asymmetry by Blue Tits () Ismael Galván
}

\section{To cite this version:}

Ismael Galván. Ultraviolet-blue plumage colouration can be perceived as an indicator of fluctuating asymmetry by Blue Tits (). Journal für Ornithologie = Journal of Ornithology, 2010, 152 (2), pp.223230. 10.1007/s10336-010-0568-y . hal-00614849

\section{HAL Id: hal-00614849 \\ https://hal.science/hal-00614849}

Submitted on 17 Aug 2011

HAL is a multi-disciplinary open access archive for the deposit and dissemination of scientific research documents, whether they are published or not. The documents may come from teaching and research institutions in France or abroad, or from public or private research centers.
L'archive ouverte pluridisciplinaire HAL, est destinée au dépôt et à la diffusion de documents scientifiques de niveau recherche, publiés ou non, émanant des établissements d'enseignement et de recherche français ou étrangers, des laboratoires publics ou privés. 
1 Ultraviolet-blue plumage colouration can be perceived

2 as an indicator of fluctuating asymmetry by Blue Tits

3 (Cyanistes caeruleus)

4

5 Ismael Galván

6

7 Department of Evolutionary Ecology, Museo Nacional de Ciencias Naturales

8 (CSIC), José Gutiérrez Abascal 2, E-28006 Madrid, Spain

9 Present address: Department of Evolutionary Ecology, Estación Biológica de

10 Doñana (CSIC), Avda. Americo Vespucio s/n, E-41092 Sevilla, Spain

11 E-mail: ism.galvan@gmail.com

12 Phone: +34954 466700

13 Phax: +34 954621125

14

15

16 
Abstract

The expression of structural plumage colours (i.e. those generated by feather microstructures) often acts as a signal of quality, but the signal content of these traits remains relatively unknown. However, a hypothesis posits that the production of structural colouration depends on developmental stability because variation in developmental programs can affect the precise feather structures that generate structural colour. Here I test this hypothesis by exploring the relationship between crown colouration, calculated by using a model of avian visual perception, and fluctuating asymmetry (FA) of tail feathers in blue tits (Cyanistes caeruleus). As predicted, there was a negative correlation between the ultraviolet (UV)-blue reflectance of the crown patch and FA of feathers. There was indirect evidence for a relationship between fledging success and UV-blue colour, but not for a condition dependence of this trait. These results suggest that the signal content of the structural colouration of blue tits may be information regarding individuals' developmental stability. As the colour components of the crown colouration were calculated with an avian visual perception model, this indicates that blue tits can perceive differences in FA through variation in the expression of structural colour.

Keywords communication · developmental stability · structural colouration · visual perception

\section{Zusammenfassung}

\section{Ultraviolettblaue Gefiederfärbung als Indikator für variable Asymmetrie bei Blaumeisen} Cyanistes cearuleus

Die Ausprägung der strukturellen Gefiederfarben (z. B. erzeugt durch Mikrostrukturen in Federn) ist oftmals ein Zeichen für Qualität, wobei aber der Signalgehalt dieses Merkmals relativ unbekannt ist. Eine Hypothese besagt, dass die Bildung der strukturellen Färbung abhängig ist von einer stabilen Entwicklung, da Variation in der Entwicklung die genaue 
44 Federstruktur, welche die strukturellen Farben generiert, beeinflussen kann. Mittels der

45 Analyse der Beziehung zwischen Kronenfärbung, berechnet mit Hilfe eines Modells zur

46 visuellen Wahrnehmung bei Vögeln, und der variablen Asymmetrie (FA) der Steuerfedern von

47 Blaumeisen Cyanistes cearuleus, testete ich diese Hypothese. Wie erwartet, konnte eine

48 negative Korrelation zwischen der ultraviolett-blauen (UV) Reflexion des Kronenflecks und der

49 FA der Federn nachgewiesen werden. Auch gab es indirekte Hinweise auf einen

50 Zusammenhang zwischen Bruterfolg und der ultraviolett-blauen Färbung, jedoch nicht

51 hinsichtlich einer Konditionsabhängigkeit dieses Merkmals. Die Ergebnisse zeigen, dass der

52 Signalgehalt der strukturellen Färbung bei Blaumeisen Informationen hinsichtlich der

53 Entwicklungsstabilität bei Individuen beinhalten könnte. Da die Farbkomponenten der

54 Kronenfärbung über ein Modell zur visuellen Wahrnehmung bei Vögeln berechnet wurden,

55 deutet dies darauf hin, dass Blaumeisen Unterschiede in der FA über die Variation der

56 strukturellen Farben erkennen können.

57

58

59

60

61

62

63

64

65 


\section{Introduction}

Structural plumage colouration is generated by the optical effects of light waves interacting with the matrix of keratin and air of feathers, and is responsible for the blue and ultraviolet (UV) hues of several bird species (Prum 2006). These colour traits are often involved in processes of mate choice (Hill 2006). Plumage signals produced by pigment-based colours (e.g., melanins or carotenoids) are generally thought to be the product of trade-offs between allocating pigments to that signal vs. physiological maintenance. Theory predicts that only high quality individuals will be able to afford large concentrations of pigments to signalling (e.g. Alonso-Alvarez et al. 2008; Galván and Alonso-Alvarez 2008; Mougeot et al. 2009). The signal content of structural colours is controversial however, as the feather nanostructures that produce these colours may not be constructed from any limited nutrients, and thus no developmental constraints may act on these structures (Prum 2006).

Recent studies suggest that the expression of structural plumage colours may be constrained by diet, condition, developmental stability and environmental stressors. First, Peters et al. (2007) showed that the expression of structural plumage colouration depends on the availability of protein necessary to produce the structural components of feathers (i.e. keratin), and other studies have shown that the production of some types of structural plumage colouration is related to nutritional condition (Keyser and Hill 1999; Doucet 2002; McGraw et al. 2002; Johnsen et al. 2003). Second, the production of melanins is limited to high quality individuals that are able to afford the antioxidant costs of these pigments (Galván and AlonsoAlvarez 2008, 2009) or to gain access to melanin precursors (Poston et al. 2005). As the presence of melanin layers in feathers are necessary to produce structural colours (Shawkey and Hill 2006), the costs of producing melanins may indeed represent costs for producing structural colouration. Lastly, some analyses suggest that structural colour expression depends upon the nanoscale regularity of the spongy layer of keratin in feather barbs (Shawkey et al. 2003), and similar results linking colour expression to nanostructure variables related to developmental instability have been reported in insects (Kemp et al. 2006). These latter results suggest that only individuals able to mount a proper developmental program or to resist the 
effects of environmental stressors can express structural colouration at a high degree (Shawkey et al. 2003; Kemp et al. 2006). Thus, the honesty of structural plumage colouration may be mediated by developmental constraints, which may be generated by individual differences in either the expression of genes that control developmental stability (Fitzpatrick 1998; Andersson 1999; Örnborg et al. 2002; Shawkey et al. 2003; Siefferman and Hill 2005) or in the capacity to afford costs associated with environmental stressors (Kemp et al. 2006).

My aim here is to examine the relationship between characteristics of a structurally produced plumage colour and developmental stability, as measured by fluctuating asymmetry (FA) of tail feathers, in the blue tit (Cyanistes caeruleus) (Fitzpatrick 1998; Andersson 1999; Örnborg et al. 2002; Shawkey et al. 2003; Siefferman and Hill 2005). FA is the deviation from the symmetry of a bilateral trait as a consequence of the incapacity of an organism to perform a developmental program, so FA of tail feathers can be used as a proxy for the developmental stability experienced by birds (Møller and Swaddle 1997). I used tail feathers because FA has been measured in this trait in several species of birds, which has been shown to reflect phenotypic quality (Møller 1991; Møller and Höglund 1991; Aparicio and Bonal 2002), and is a non-destructive and easy method to estimate FA in live birds.

The blue tit is a small passerine bird that presents a structural blue crown plumage patch that is sexually dimorphic regarding UV reflectance (Andersson et al. 1998; Hunt et al. 1998). A large body of evidence exists to support a role of crown UV reflectance as an honest signal in intraspecific communication (Alonso-Alvarez et al. 2004; Poesel et al. 2007). In particular, male UV-reflectance predicts annual survival and reproductive success (Sheldon et al. 1999; Delhey et al. 2003; Griffith et al. 2003), and females mated to more UV reflective males produce more sons and provide more parental care and nest defense (Sheldon et al. 1999; Griffith et al. 2003; Limbourg et al. 2004; Johnsen et al. 2005; Korsten et al. 2006). Furthermore, there is some evidence that female crown UV reflectance may also be a signal used by males when choosing mates (Andersson et al. 1998; Hunt et al. 1998; but see Delhey et al. 2007). However, the mechanisms mediating the honesty of blue tit crown colouration remain unknown (Peters et al. 2007). 
I predicted that, if the structural plumage colour of blue tits reflects the capacity of birds to perform a tight developmental control of feather elements and thus the developmental stability of birds, high quality individuals (i.e. those presenting high UV-reflectance in the crown patch, see above) should present low FA levels in their feathers. UV colouration and FA levels should thus be negatively correlated. I use current models of avian colour vision (Vorobyev et al. 1998; Endler and Mielke 2005) to estimate crown colour components that are perceived by blue tits and thus have the potential to be significant in intraspecific signalling.

\section{Methods}

The study was carried out in May-June 2007 in a deciduous forest of Pyrennean Oak Quercus pyrenaica in Miraflores de la Sierra, central Spain $\left(40^{\circ} 49^{\prime} \mathrm{N}, 03^{\circ} 46^{\prime} \mathrm{W}\right)$. Frequent checks of nest-boxes allowed me to determine the date of clutch initiation and clutch size for all breeding pairs. A total of 34 blue tits ( 16 males and 18 females, representing 15 adults, 15 yearlings and four individuals of unknown age) were captured at the nest-boxes on day six (hatching day = day 0), and classified as yearlings or older according to plumage (Jenni and Winkler 1994). Individuals were uniquely marked with metallic rings, weighed with a portable electronic balance and their tarsus length measured with a digital calliper. The fifth pair of rectrix feathers was plucked in each bird and stored in a bag until measurements were made. The length of the feathers was measured by putting them straight on a piece of polystyrene and marking with two entomological pins the extreme points of the feathers, that is, the base of the calamus and the end of the rachis. The distance between pins was then measured with a digital calliper. All feathers were measured twice, but both measurements were made on different days to avoid unconscious bias in determining feather length. FA was calculated as the absolute value of the difference between the average length of the left and the right rectrix feathers $(|L-R|)$, as this value was not correlated with trait size (Møller and Swaddle 1997; see Results).

On day 15 , the nestlings were weighed and their tarsus length measured. After day 15 , the nest-boxes were inspected shortly after all nestlings had fledged to search for dead 
nestlings or cues of predation, but none were found. Thus, the number of fledglings on day 15 divided by clutch size was used as an estimate of fledging success (e.g. Sanz et al. 2001).

\section{Reflectance spectrometry}

Plumage reflectance measurements were taken from the crown patch of blue tits. Data were collected in the field using an Ocean Optics USB2000 spectrophotometer (range 250-800 nm) with ultraviolet (deuterium) and visible (tungsten-halogen) lamps and a bifurcated 400 micrometer fiber-optic probe (Dunedin, Florida, USA). The fiber optic probe both provided illumination and obtained light reflected from the sample, and had a reading area of $\sim 1 \mathrm{~mm}^{2}$. The measurements were taken at a $90^{\circ}$ angle to the sample. The spectrometer measured reflectance in $0.36 \mathrm{~nm}$ increments. All measurements were relative to a white "Spectralon" tablet (WS-1-SS, Ocean Optics, Dunedin, Florida, USA), and the system was frequently calibrated. The spectral curves were generated by using OOIBase software. Three readings were obtained for each individual. The probe was removed between each measurement, but each replicate reading was taken from the same point on the crown. The results of reflectance measurements are shown in Fig. 1.

\section{Visual modeling}

Colour vision in diurnal birds is dependent upon four types of retinal cone cells which are sensitive to either very short (VS, ultraviolet (UV)), short (SWS, blue), medium (MWS, green) or long (LWS, red) wavelengths (Maier and Bowmaker 1993; Cuthill 2006). Spectral data were reduced into four quantal cone catches (Vorobyev et al. 1998) that quantify the amount of light captured by each of the single cones. By using the SPEC package (Hadfield and Owens 2006) implemented in $\mathrm{R}$ (R Development Core Team 2004), the four quantum cone catches $\left(Q_{i}\right)$ were calculated by multiplying cone sensitivities by the reflectance spectrum, the irradiance spectrum and the transmission spectrum of the ocular media, as expressed by the formula: 


$$
Q_{i}=\frac{\int_{i} R_{i}(\lambda) S(\lambda) I(\lambda) O(\lambda) d(\lambda)}{\int_{i=1} R_{i}(\lambda)},
$$

176 where $/ 3$ indicates wavelength $(\mathrm{nm}), R_{i}(\lambda)$ is the sensitivity $(\mathrm{nm})$ of cone type $i, S(\lambda)$ is the 177 percent of light reflected from a patch compared to a white standard, $I($ is the irradiance 178 spectrum $\left(\mu \mathrm{mol} \cdot \mathrm{m}^{-2} \cdot \mathrm{s}^{-1} \cdot \mathrm{nm}^{-1}\right)$ and $O($ is the transmittance spectrum of the ocular media. animals through colour constancy, the von Kreis algorithm was used to normalise $Q_{i}$ by the quantum cone catch for the irradiance spectrum. The irradiance spectral data used were obtained from a standard forest shade illumination provided by the SPEC package (Hadfield and Owens 2006), as this irradiance spectrum is the most appropriate for our case (see habitat description above), and an achromatic adapting background (Hadfield and Owens 2006). I used the ocular media transmittance of the blue tit (Hart et al. 2000). Each cone catch was then standardized by dividing them by the sum of the four cone catches, and three of the standardized cone catches were divided by a fourth (that corresponding to LWS in this case) and their natural logarithm was then calculated. Thus, three log-contrasts were calculated to break the unit-sum of the four standardized cone catches (Hadfield and Owens 2006; Galván et al. 2009; Galván 2010). In addition, these log-contrasts permit considering an opponency model of colour vision where the exact opponency mechanisms are unspecified, as perception of chromatic variation occurs through a physiological mechanism that contrasts the relative outputs of the different cone types (Endler and Mielke 2005; Hadfield and Owens 2006). performed on the three log-contrast colour variables in order to treat them as a multivariate response in a multivariate 'animal model'. The eigendecomposition showed an axis (PC1) that explained $75.7 \%$ of phenotypic variation (eigenvalue $=2.27$; mean \pm SE: $0.00 \pm 0.16$; range: 1.73-2.94; $n=38)$ ). The factor loadings for PC1 were high and positive for the first two log- 
200

201

202

203

204

205

206

207

208

209

210

211

212

213

214

215

216

217

218

219

220

221

222

223

224

225

226

log-contrast (0.67), indicating that it is determined by the two first cone catches vs. LWS. Thus, high PC1 scores indicate relatively more reflectance at short (i.e. UV-blue) wavelengths as compared to long (i.e. red) wavelengths.

As achromatic variation in birds is thought to not be perceived through the four single cones, but by double cones (Campenhausen and Kirschfeld 1998; Osorio et al. 1999), I calculated the double cone quantum catches from data on double cone spectral sensitivity of blue tits following the same procedure for the four single cones. The double cone quantum catch was used as a 'brightness index' (mean \pm SE: $0.05 \pm 0.00$; range: $0.01-0.11 ; n=38$ ). This brightness index was negatively correlated with PC1 scores in the blue tits (Pearson correlation test: $r=-0.57, n=34, P<0.0001)$.

\section{Analyses of FA}

Some preliminary analyses were performed to determine if the distribution of L-R values was due to FA or to any other type of asymmetry (van Dongen et al. 1999). First, I tested whether the distribution of L-R values differed from a normal distribution through a Shapiro-Wilks test, and whether the mean value significantly differed from zero through a one-sample t-test. To estimate the magnitude of FA in relation to measurement error and directional asymmetry (DA), a mixed model was performed in which random effects were estimated with a restricted maximum-likelihood (REML) approach (van Dongen et al. 1999). In this model, trait size was a function of side (fixed effect) + individual (random effect) + side nested in individual (random effect) + measurement error (random effect). FA and DA are represented by the random side effect and the fixed side effect, respectively (e.g. Stige et al. 2005, 2006). In addition, I tested whether the skewness and kurtosis of the distribution of L-R values significantly differed from zero according to Zar (1999). To test whether FA depended on trait size, I performed a Pearson correlation test on standardized (mean $=0, S D=1)|L-R|$ values and standardized mean values of feather length for each bird. 
227 Statistical analyses

228 To test for a relationship between crown colouration and FA, General Linear Models (GLM) 229 were performed with each of the colour parameters (i.e. PC1 and brightness index) as a 230 dependent variable. The saturated models included sex and age as fixed factors and FA as a 231 covariate. The interaction between sex and FA was also included because crown colouration is 232 a sexually dichromatic trait in blue tits (e.g. Andersson et al. 1998; Delhey et al. 2003, 2006), 233 which suggests that trait expression may be differentially constrained in males and females 234 (Delhey et al. 2003) and thus FA may have different effects on crown colouration in both sexes. 235 The interaction between age and FA was not included because there were no a priori reasons to test for differences in the relationship between FA and crown colour between age classes.

Similar models were performed to test for a relationship between crown colouration and body condition, including this latter variable as a covariate. Body condition was expressed as body mass divided by the cube of tarsus length (Galván 2010), and the same analyses were repeated using the residuals of body mass regressed on tarsus length as an alternative measurement of condition. Although the measurements of condition taken for the present study may not reflect the condition of birds at moult (i.e. end of summer), changes in body mass between winter and spring are small and probably not related to changes in body condition in blue tits (Delhey et al. 2006), so that body condition in spring is likely to reflect condition when the feathers were developed like in the closely related great tit (Parus major) (Gosler and Harper 2000).

To test for a relationship between crown colouration and different parameters of breeding success, laying date (log-transformed), nestling mass, nestling condition (calculated as in the parents) and fledging success (arcsine-square-root-transformed) were included as dependent variables in separate GLMs with sex, age and the interaction between sex and the colour parameters.

In all cases, inspections of the distribution of residuals confirmed that the normality assumption was fulfilled. The presence of outliers was determined on the basis of Cook's 
254

255

256

257

258

259

260

261

262

263

264

265

266

267

268

269

270

271

272

273

274

275

276

277

278

distances greater than 2 and leverages greater than $2 p / n$, where $p$ is the number of parameters in the model and $n$ is the sample size (Crawley 1993).

\section{Results}

\section{Measurement error and asymmetry distribution}

$|\mathrm{L}-\mathrm{R}|$ values were not significantly correlated with trait size $(r=-0.24, n=34, P=0.177)$, so that these untransformed absolute values were used as an estimate of FA in subsequent analyses (mean FA \pm SE: $0.29 \pm 0.04 \mathrm{~cm}$; range: $0.00-0.72 \mathrm{~cm} ; n=34$ ). The distribution of L-R values did not differ significantly from a normal distribution ( $W=0.96, P=0.328)$, and the mean of this distribution did not differ significantly from zero $(t=1.10, d f=33, P=0.277)$.

Although the measurement error was large $(Z=5.83, P<0.0001)$, FA was significantly related to the variance in tail feather length $(Z=5.73, P<0.0001)$, while DA was not $\left(F_{1,66}=\right.$ $0.02, P=0.893)$. The distribution of $L-R$ values was symmetrical and mesokurtic as derived from a skewness $\left(g_{1}=-0.108\right)$ and a kurtosis $\left(g_{2}=-0.435\right)$ not significantly different from zero $\left(Z_{g 1}=-1.02, P=0.308 ; Z_{g 2}=0.76, P=0.447\right)$. More specifically, although the kurtosis was negative, the distribution was not platykurtic because the one-tailed P-value was still not significant $(P=0.224)$. Therefore, the tail feather length of blue tits presented size-independent FA and not other types of asymmetry, after controlling for measurement error.

\section{Relationship between crown colouration and tail FA}

Age was not significantly correlated with colour PC1 $\left(F_{1,25}=1.48, P=0.235\right)$, and was therefore removed from the model. The same was done with the interaction between sex and $\mathrm{FA}\left(F_{1,30}=\right.$ 1.23, $P=0.276$ ). The model obtained explained $35.4 \%$ of variance in colour PC1 scores and included sex $\left(F_{1,31}=14.61, P=0.001\right)$ and $\mathrm{FA}\left(F_{1,31}=4.78, P=0.036\right)$, indicating that males presented more relative UV reflectance than females (least squares mean \pm SE, males: $0.69 \pm$ 
279

280

281

282

283

284

285

286

287

288

289

290

291

292

293

294

295

296

297

298

299

300

301

302

303

304

0.20 , females: $-0.39 \pm 0.19$; Fig. 1$)$ and that colour PC1 was negatively correlated with FA ( $b=-$ 1.29, $t=-2.19, P=0.036$; Fig. 2). There was an adult male that presented a very high PC1 score and may thus represent an outlier (see Fig. 2), but a Cook's distance lower than $2(0.46)$ and a leverage lower than $2 p / n(0.09 ; 2 p / n=0.18)$ indicated that it was not. In any case, the effect of FA remained close to significance when this point was removed $\left(F_{1,30}=3.91, P=\right.$ 0.057).

In contrast, only age was significantly related to the brightness index of blue tits $\left(F_{1,28}=\right.$ $5.71, P=0.024$; least squares mean \pm SE, yearlings: $0.05 \pm 0.00$, adults: $0.04 \pm 0.00$ ). Neither FA $\left(F_{1,26}=0.02, P=0.881\right)$, sex $\left(F_{1,27}=0.46, P=0.504\right)$ or their interaction $\left(F_{1,25}=0.20, P=\right.$ $0.657)$ contributed to explain variance in the brightness index.

Relationship between crown colouration and body condition

Body condition measured as body mass divided by the cube of tarsus length was not significantly related to colour PC1 $\left(F_{1,29}=0.73, P=0.399\right)$ after controlling for the effects of sex $\left(F_{1,29}=10.02, P=0.004\right.$; least squares mean \pm SE: males: $0.59 \pm 0.23$, females: $\left.-0.38 \pm 0.20\right)$ and age $\left(F_{1,29}=3.34, P=0.078\right)$. The interaction between sex and condition was not significant either $\left(F_{1,28}=0.03, P=0.860\right)$. Similarly, brightness index did not depend on the body condition of birds $\left(F_{1,29}=0.92, P=0.344\right)$, and only age had an effect $\left(F_{1,31}=10.32, P=0.003\right.$; least squares mean $\pm \mathrm{SE}$ : yearlings: $0.06 \pm 0.00$, adults: $0.03 \pm 0.00$; sex: $F_{1,30}=1.71, P=0.200$; sex $\mathrm{x}$ condition: $\left.F_{1,28}=0.05, P=0.820\right)$. The same results were obtained when the residuals of tarsus length regressed against body mass were used as an estimate of body condition (results not shown).

\section{Relationship between crown colouration and breeding success}

There were no significant relationships between the colour parameters and laying date, nestling body mass, nestling condition or fledging success (results not shown), with the exception of an 
305

306

307

308

309

310

311

effect of brightness index on fledging success that was close to significance $\left(b=-7.28, F_{1,30}=\right.$ 3.63, $P=0.066)$ after controlling for the effects of $\operatorname{sex}\left(F_{1,29}=0.01, P=0.903\right)$, age $\left(F_{1,27}=0.11\right.$, $P=0.744)$ and the interaction between sex and brightness index $\left(F_{1,28}=0.00, P=0.952\right)$, which indicates that fledging success tended to decrease with increasing the crown brightness of the parents.

\section{Discussion}

As predicted, the relative UV-blue reflectance of the crown plumage of blue tits was negatively related to the FA of tail feathers. This suggests that the developmental stability experienced by birds is reflected in the colour properties of feathers. As plumage colouration was measured through a model of avian colour vision, this result indicates that blue tits have the potential to perceive the developmental stability of conspecifics through the evaluation of UV-blue colour. Thus, the present study provides some correlational evidence for the hypothesis that structural colours signal the capacity of individuals to perform a tight developmental control of feather elements (Fitzpatrick 1998; Andersson 1999; Örnborg et al. 2002; Shawkey et al. 2003; Siefferman and Hill 2005), as FA measures the capacity of individuals to perform a developmental program of morphological structures (Møller and Swaddle 1997).

On the other hand, I found weak evidence for condition dependence of the blue tit crown colouration. Although many types of biological signals exist (Hasson 1997), most of our current understanding on honest signalling comes from the Handicap Principle (Zahavi 1975), which establishes that variation in the expression of the signals is due to inter-individual differences in the capacity to afford certain costs. These costs are generated by environmental influences, and thus the expression of handicap signals is strongly environmentally dependent, which means that a relationship between signal expression and individual condition must exist (Zahavi 1975; Grafen 1990). In the case of the structural colour of blue tits, Johnsen et al. (2003) and Peters et al. (2007) found a positive correlation between UV chroma (a physical measurement of UV relative reflectance) and body condition in nestlings, which led other 
332

333

334

335

336

337

338

339

340

341

342

343

344

345

346

347

348

349

350

351

352

353

354

355

356

357

358

359

authors to assume that a similar relationship between structural colouration and condition might exist in adults (Limbourg et al. 2004), but to my knowledge there are no published reports of relationships with body condition in adult blue tits. It is thus possible that the lack of correlation between crown UV-blue reflectance and body condition in the present study represents a general pattern and the crown colouration is not a condition-dependent trait in blue tits. However, the results presented here support the view of this trait as a signal of individual quality, as fledging success tended to increase with an index of plumage brightness as might be perceived by birds, which is in turn positively related to UV-blue reflectance (see Methods), independently of sex. This is in accordance to several previous studies showing fitness benefits for the more reflectant males (Sheldon et al. 1999; Delhey et al. 2003; Griffith et al. 2003; Limbourg et al. 2004; Johnsen et al. 2005; Korsten et al. 2006) and mutual mate choice based on this trait (Andersson et al. 1998; Hunt et al. 1998). Therefore, the colour properties of the blue tit crown patch may signal quality through other mechanisms different from costs, i.e. by signalling 'good genes'.

FA is produced by differences in the capacity of genotypes to produce a phenotype under certain environmental conditions (Møller and Thornhill 1998). This measurement of developmental stability has an important role in sexual selection, probably because it is correlated with different individual attributes (Møller and Thornhill 1998), and is also negatively related to several components of fitness (Møller 1997). The present study shows that blue tits can perceive differences in FA by the observed variability in UV-blue reflectance of the crown plumage patch, and that this colour trait is not condition-dependent. This suggests that the signal content of the blue tit structural colouration may be the capacity of the genotype to produce a certain phenotype (i.e. crown colour). To my knowledge, this is the first time that a measurement of developmental stability is related to the expression of structural plumage colouration as might be perceived by birds. Future studies should investigate the structural components of feathers that are more dependent upon the capacity of individuals to perform a developmental program and how these components affect the expression of structural colour traits that can be perceived by birds. 


\section{Acknowledgments}

The Consejería de Medio Ambiente y Ordenación del Territorio of Comunidad de Madrid provided me with the licenses required to carry out the study.

\section{References}

Alonso-Alvarez C, Doutrelant C, Sorci G (2004) Ultraviolet reflectance affects male-male interactions in the blue tit (Parus caeruleus). Behav Ecol 15:805-809

Alonso-Alvarez C, Pérez-Rodríguez L, Mateo R, Chastel O, Viñuela J (2008) The oxidation handicap hypothesis and the carotenoid allocation trade-off. J Evol Biol 21:1789-1797

Andersson S (1999) Morphology of UV reflectance in a whistling-thrush: implications for the study of structural colour signalling in birds. J Avian Biol 30:193-204

Andersson S, Örnborg J, Andersson M (1998) Ultraviolet sexual dimorphism and assortative mating in blue tits. Proc R Soc B 265:445-450

Aparicio JM, Bonal R (2002) Why do some traits show higher fluctuating asymmetry than others? A test of hypotheses with tail feathers of birds. Heredity 89:139-144

Campenhausen MV, Kirschfeld K (1998) Spectral sensitivity of the accessory optic system of the pigeon. J Comp Physiol A 183:1-6

Crawley MJ (1993) GLIM for ecologists. Blackwell Science., Oxford

Cuthill IC (2006) Color Perception. In: Hill GE, McGraw K (eds) Bird Coloration, Vol I: Mechanisms and Measurements. Harvard University Press, Cambridge, pp 3-40

Delhey K, Johnsen A, Peters A, Andersson S, Kempenaers B (2003) Paternity analysis reveals opposing selection pressures on crown coloration in the blue tit (Parus caeruleus). Proc. R. Soc. B $270: 2057-2063$ 
384

385

386

387

388

389

390

391

392

393

394

395

396

397

398

399

400

401

402

403

404

405

406

407

Delhey K, Johnsen A, Peters A, Andersson S, Kempenaers B (2006) Seasonal changes in blue tit crown color: do they signal individual quality? Behav Ecol 17:790-798

Delhey K, Peters A, Johnsen A, Kempenaers B (2007) Fertilization success and UV ornamentation in blue tits Cyanistes caeruleus: correlational and experimental evidence. Behav Ecol 18:399-409

Doucet SM (2002) Structural plumage coloration, male body size, and condition in the blueblack grassquit. Condor 104:30-38

Endler JA, Mielke PW (2005) Comparing entire colour patterns as birds see them. Biol J Linn Soc $86: 405-431$

Fitzpatrick S (1998) Colour schemes for birds: structural coloration and signals of quality in feathers. Ann Zool Fenn 35:67-77

Galván I (2010) Plumage coloration can be perceived as a multiple condition-dependent signal by Great Tits Parus major. Ibis 152:359-367

Galván I, Alonso-Alvarez C (2008) An intracellular antioxidant determines the expression of a melanin-based signal in a bird. PLoS ONE 3:e3335

Galván I, Alonso-Alvarez C (2009) The expression of melanin-based plumage is separately moduated by exogenous oxidative stress and a melanocortin. Proc R Soc B 276:30893097

Galván I, Díaz L, Sanz JJ (2009) Relationships between territory quality and carotenoid-based plumage colour, cell-mediated immune response, and body mass in Great Tit Parus major nestlings. Acta Ornithol 44:139-150

Gosler AG, Harper DGC (2000) Assessing the heritability of body condition in birds: a challange exemplified by the great tit Parus major L. (Aves). Biol J Linn Soc 71:103-117

Grafen A (1990) Biological signals as handicaps. J Theor Biol 144:517-546 
408 Griffith SC, Örnborg J, Russell AF, Andersson S, Sheldon BC (2003) Correlations between 409 ultraviolet coloration, overwinter survival and offspring sex ratio in the blue tit. J Evol Biol 16:1045-1054

Hadfield JD, Owens IPF (2006) Strong environmental determination of a carotenoid-based plumage trait is not mediated by carotenoid availability. J Evol Biol 19:1104-1114

Hart NS, Partridge JC, Cuthill IC, Bennett ATD (2000) Visual pigments, oil droplets, ocular 414 media and cone photoreceptor distribution in two species of passerine bird: the blue tit (Parus caeruleus L.) and the blackbird (Turdus merula L.). J Comp Physiol A 186:375-

Hasson O (1997) Towards a general theory of biological signaling. J Theor Biol 185:139-156

Hill GE (2006) Female mate choice for ornamental coloration. In: Hill GE, McGraw KJ (eds) Bird Coloration, Vol II: Function and Evolution. Harvard University Press, Cambridge, pp

Hunt S, Bennett ATD, Cuthill IC, Griffiths R (1998) Blue tits are ultraviolet tits. Proc R Soc B

Jenni L, Winkler R (1994) Moult and Ageing of European Passerines. Academic Press, London

Kemp DJ, Vukusic P, Rutowski RL (2006) Stress-mediated covariance between nano-structural 431 architecture and ultraviolet butterfly coloration. Funct Ecol 20:282-289 
432

433

434

435

436

437

438

439

440

441

442

443

444

445

446

447

448

449

450

451

452

453

454

455

456

Keyser AJ, Hill GE (1999) Condition-dependent variation in the blue-ultraviolet coloration of a structurally-based plumage ornament. Proc R Soc B 265:771-777

Korsten P, Lessells CM, Christa Mateman A, van der Velde M, Komdeur J (2006) Primary sex ratio adjustment to experimentally reduced male UV attractivenes in blue tits. Behav Ecol 17:539-546

Limbourg T, Mateman AC, Andersson S, Lessells CM (2004) Female blue tits adjust parental effort to manipulated male UV attractiveness. Proc R Soc B 271:1903-1908

Maier EJ, Bowmaker JK (1993) Colour vision in the passeriform bird, Leiothrix lutea: Correlation of visual pigment absorbency and oil droplet transmission with spectral sensitivity. J Comp Physiol A 172:295-301

McGraw KJ, Mackillop EA, Dale J, Hauber M (2002) Different colors reveal different information: how nutritional stress affects the expression of melanin- and structurally based ornamental plumage. J Exp Biol 205:3747-3755

Møller AP (1991) Sexual ornament size and the cost of fluctuating asymmetry. Proc R Soc B 243:59-62

Møller AP (1997) Developmental stability and fitness: a review. Am Nat 149:916-932

Møller AP, Höglund J (1991) Patterns of fluctuating asymmetry in avian feather ornaments: implications for models of sexual selection. Proc R Soc B 245:1-5

Møller AP, Swaddle JP (1997) Asymmetry, developmental stability, and evolution. Oxford University Press, Oxford

Møller AP, Thornhill R (1998) Bilateral symmetry and sexual selection: a meta-analysis. Am Nat $151: 174-192$

Mougeot F, Martínez-Padilla J, Webster LM, Blount JD, Pérez-Rodríguez L, Piertney SB (2009) Honest sexual signalling mediated by parasite and testosterone effects on oxidative balance. Proc R Soc B 276:1093-1100 
457 Örnborg J, Andersson S, Griffith SC, Sheldon BC (2002) Seasonal changes in a ultraviolet 458 structural colour signal in blue tits, Parus caeruleus. Biol J Linn Soc 76:237-245

459 Osorio D, Miklosi A, Gonda Z (1999) Visual ecology and perception of coloration patterns by $460 \quad$ domestic chicks. Evol Ecol 13:673-689

461 Peters A, Delhey K, Johnsen A, Kempenaers B (2007) The condition-dependent development 462 of carotenoid-based and structural plumage in nestling blue tits: males and females differ. Am Nat 169:S122-S136

Poesel A, Dabelsteen T, Darden S-K, Delhey K, Peters A (2007) Territorial responses of male 465 blue tits, Cyanistes caeruleus, to UV-manipulated neighbours. J Ornithol 148:179-187

Poston JP, Hasselquist D, Stewart IRK, Westneat DF (2005) Dietary amino acids influence 467 plumage traits and immune responses of male house sparrows, Passer domesticus, but

Prum RO (2006) Anatomy, physics, and evolution of structural colours. In: Hill GE, McGraw KJ (eds) Bird coloration, Volume I: Mechanisms and Measurements. Harvard University Press, Cambridge, pp 295-353

R Development Core Team (2004) R: a Language and Environment for Statistical Computing. R Foundation for Statistical Computing, Vienna

Sanz JJ, Arriero E, Moreno J, Merino S (2001) Female hematozoan infection reduces hatching 475 success but not fledging success in Pied Flycatchers Ficedula hypoleuca. Auk 118:750755

Shawkey MD, Hill GE (2006) Significance of a basal melanin layer to production of non478 iridescent structural plumage color: evidence from an amelanotic Steller's jay (Cyanocitta stelleri). J Exp Biol 209:1245-1250 
482 Sheldon BC, Andersson S, Griffith SC, Örnborg J, Sendecka J (1999) Ultraviolet colour $483 \quad$ variation influences blue tit sex ratios. Nature 402:874-877

484 Siefferman L, Hill GE (2005) UV-blue structural coloration and competition for nestboxes in 485 male eastern bluebirds. Anim Behav 69:67-72

Stige LC, Slagsvold T, Vøllestad LA (2005) Individual fluctuating asymmetry in pied flycatchers 487 (Ficedula hypoleuca) persists across moults, but is not heritable and not related to fitness. Evol Ecol Res 7:381-406

Stige LC, Hessen DO, Vøllestad LA (2006) Fitness, developmental instability, and the ontogeny 490 of fluctuating asymmetry in Daphnia magna. Biol J Linn Soc 88:179-192

van Dongen S, Molenberghs G, Matthysen E (1999) The statistical analysis of fluctuating 492 asymmetry: REML estimation of a mixed regression model. J Evol Biol 12:94-102

Vorobyev M, Osorio D, Bennett ATD, Marshall NJ, Cuthill IC (1998) Tetrachromacy, oil droplets 494 and bird plumage colours. J Comp Physiol A 183:621-633

Zahavi A (1975) Mate selection - A selection for a handicap. J Theor Biol 53:205-214 
505 Fig. 1 Reflectance curves ( \pm SE) for the crown plumage patch of male (solid symbols) and 506 female (open symbols) Blue Tits.

507

508 Fig. 2 Relationship between the scores of crown colour PC1 (relative UV reflectance as might 509 be perceived by birds) and fluctuating asymmetry of tail feathers (absolute values of the 510 difference between the left and the right fifth rectrix feathers) in Blue Tits. The upper point of the 511 figure is not an outlier on the basis of statistical criteria. The line is the regression line.

512

513

514

515

516

517

518

519

520

521

522

523

524

525

526 


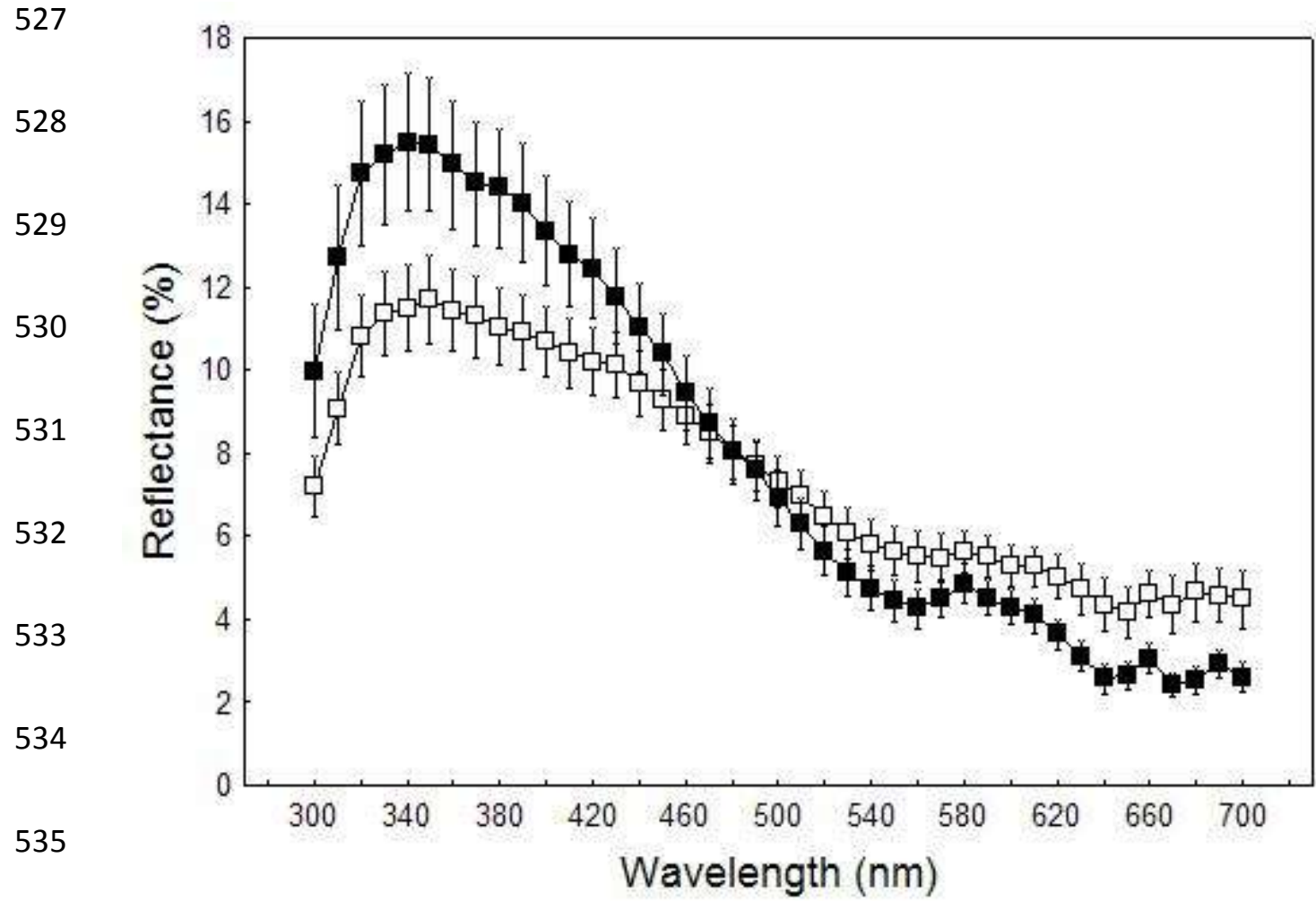

536

537 Figure 1

538

539

540

541

542

543

544

545

546 
548

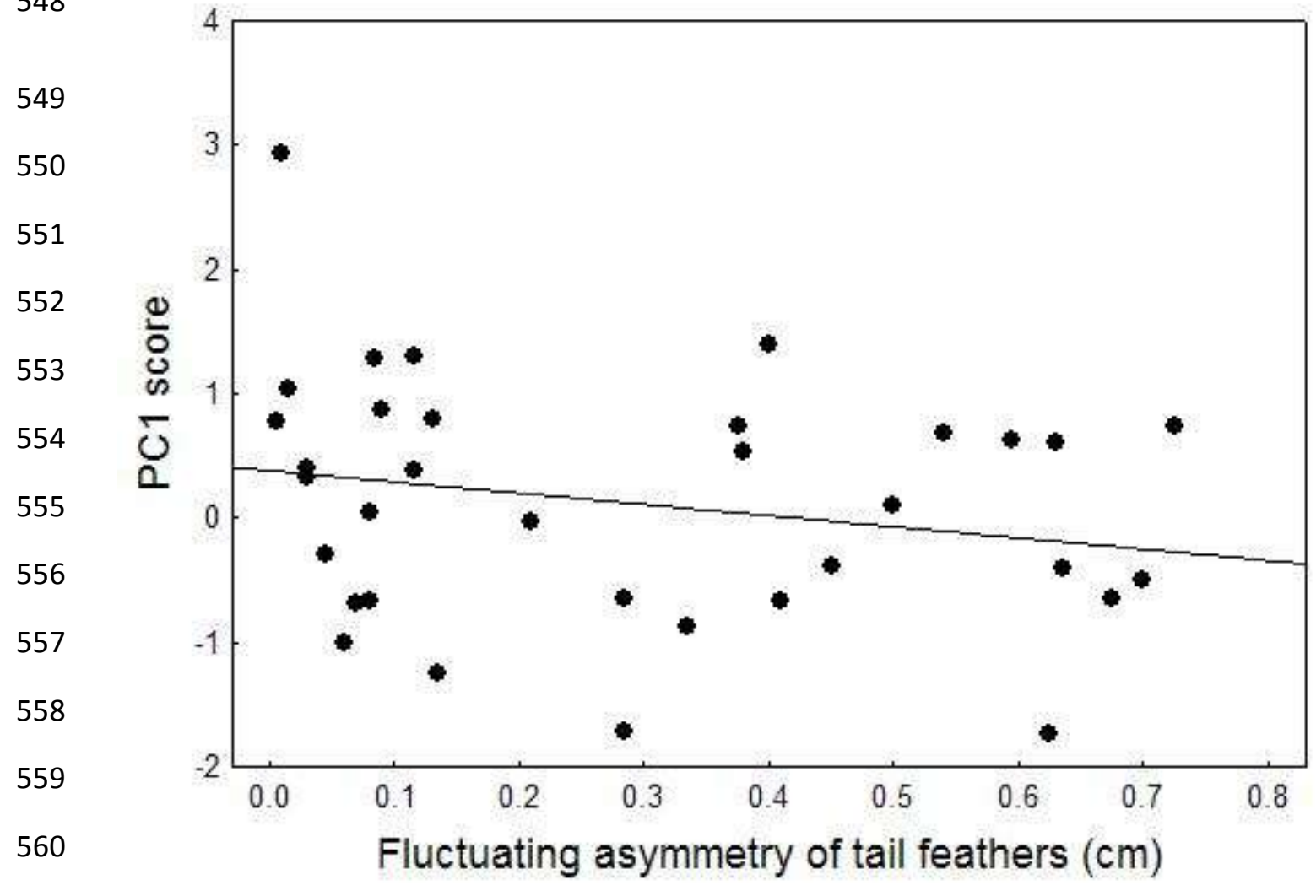

561

562 Figure 2

563

564

565

566

567

568

569

570

571

572

573

574 